\title{
The Application of Comics in Science Education
}

\author{
Marta Koutníková* \\ Received: November 5, 2017; received in revised form: November 20, 2017; \\ accepted: November 21, 2017
}

\begin{abstract}
:
Introduction: This study presents the results of a year-long project focused on analysis and reflection on working with comics by students in the preschool teacher training programme.

Methods: This study presents the use of comics to help pre-literacy children understand certain physical phenomena. The study is based on observations of changing perception of phenomena by children as a result of the use of comics accompanied by concept maps.

Results: Comics are proven to be a modern pedagogical strategy, which is starting to gain its popularity in teaching about nature study. It is used in research-oriented teaching within the psycho-didactic concept of instruction.

Conclusions: Comics can be very helpful in making science concepts interesting and comprehensible for a preschool child.
\end{abstract}

Key words: comics, teaching nature study, research-oriented teaching.

\section{Introduction}

Preschool children are at the best age for beginning to explore, mainly because they are in their early life, enter the society and begin to discover themselves and the world around them. They are constantly focused on the questions "What is it?" and "Why?" (Jakabčic, 2004). Exploration activities in preschool are based on discovering, observing, exploring and handling objects. By observing and handling objects, a child gains an impulse for further experimentation and creative activities.

Kopáčová (2003) distinguishes the following phases needed for a child's exploration:

- Setting a problem: a suitably presented question, the answer to which is found by exploring and experimenting.

- Suggesting an action: children suggest an action for carrying out the given activity.

- Aids: must be prepared in advance.

- Expressing a supposition: expectations are expressed, in our case simple children's hypotheses.

- Realisation: includes several actions; each child can choose his/her own.

- Observation: children must be shown what to focus on.

- Record of observation: in a symbolic form.

- Conclusion: to find out whether the correct answer to the question was found.

These modes of activities suggest that the low level of interest of children in the study of science, as documented by research, can be significantly raised on a life-long basis by

\footnotetext{
* Marta Koutníková, Tomas Bata University in Zlín, Faculty of Humanities, Zlín, Czech Republic; martakout@seznam.cz
} 


\section{Acta Educationis Generalis \\ volume 7, 2017, issue 3}

introducing organised forms of inquiry-based teaching in education of the youngest children.

As an example of inquiry-based teaching, the STEM programme can be mentioned, which is based on development and exploration: Science, Technology, Engineering and Maths. STEM supports the development of scientific literacy. The teacher uses it to help children ask questions, form hypotheses, look for evidence, verify it, communicate together, form conclusions based on evidence, and learn how to defend and argue these conclusions. STEM ranges education from preschool to university in order to make sure the acquired skills and knowledge are not only used in school, but also throughout life (Havice, 2014). It tries to develop knowledge in the fields of communication, problemsolving, data analysis, evidence-based arguments, creativity, constructive and critical thinking.

Research by the NSTA (National Science Teachers Association) of 2014 shows that children of preschool age are capable of understanding concepts in science. Teaching is based on using the children's activity, interest and experience, communication, and cooperation. This requirement is met by the suggestion for working with comics in this publication.

Teachers who try to bring science topics (in practical tasks) into preschools are met with effective feedback from children. This is a very positive phenomenon because research in higher stages of education has proven lack of interest in science, technology and maths, or its perception by pupils as too difficult, or unnecessary, as can be read, for example, in the report "Science education in Europe: Critical reflections" dating from 2008 (thought it must be added that compared to 2009 and 2015, the not too good results in PISA tests according to the conclusions of PISA (2009) Results: Executive Summary and PISA: Results in Focus did improve in these areas).

New opportunities for increasing and supporting children's interest in science and naturally developing their reasoning concerning its constituent parts need to be found constantly, in order for these sciences to appear in later years as quite natural and an attractive area of interest which enables us to understand the world and help it.

A range of effective teaching strategies are available. The basis is the application of constructivism processes when carrying out IBSE (Inquiry-Based Science Education). The use of suitable methods for supporting curiosity and the cultivation of ideas becomes simply indispensable. Experiments are appropriate, as well as comics use. With the latter, asking divergent questions is crucial, as well as initiating discussions in a group of children amongst themselves and with the teacher (whose role differs greatly from someone who knows, explains, describes and teaches, to someone who supports as a partner).

Comics represents an excellent way of encouraging children to think creatively. From the beginning, people have felt the specific power of picture-based stories. Pictures were the first record of history, communicated and shared with news. The mural paintings in caves thousands of years ago tell stories bursting with life; the tombs in Egypt provide details of the life of kings and slaves (and certain depictions can even be described as prehistoric comics). People who cannot communicate due to a language barrier communicate via drawings. In our everyday reality, instructions are often given in the form of images (in health care, road and air transport, in international hotels, in instructions for appliances). There are also numerous board games which are a popular pastime and use the very idea of putting across information and concepts using drawing: 


\section{Acta Educationis Generalis \\ volume 7, 2017, issue 3}

this requires structural thinking from the drawer and percipient. If people want to remember an explained route, they often draw a map. It can be said that pictures are the most comprehensible and richest communication method after language.

The communicative ability of pictures accompanies people in their formal, non-formal and informal education. They provide a quick reaction and communicate comprehensively. Such a didactic means very significantly increases the attraction of the discussed topics and aids concentration. Naturally, comics have a fundamental difference from simple pictures/illustrations, in that their function is not to represent the content of text as an additional part, or to be an accessory to a spoken idea; they are a completely independent bearer of a specific communication. Researchers studying the pedagogical use of various forms of comics (for example Tatalovic, 2009; Cheesman, 2006; Kapinabar, 2005; Wellner, 2016; Wiegerová \& Navrátilová, 2016; Svatoš \& Maněnová, 2017) agree about their advantages such as an efficient motivation for interest in a topic, an aid for concentration, the parallel development of many types of literacy, helping children discover alternative concepts, as a motivation for discussion, the opportunity to discover the level of real understanding of new knowledge after a previous educative activity and the acquisition of new scientific concepts using a constructivist approach. McClaud's revolutionary (albeit non-academic) publication "Understanding Comics" (1995) aptly outlines the implicitly necessary cooperation between the comics and the percipient, founded on shaping and constructing the reader.

\section{On the history of comics}

Opinions on the creation of the comic strip as a separate form differ. Researchers most often agree mainly on the fact that the exact beginnings of the comics cannot be dated. Groensteen (2005) labels Rodolphe Topffer's "Stories in engravings" of 1820 as a fundamental historical point in the search for the beginnings of the comic strip. McClaud (1995), who deals with the much more ancient history of the comics, also acknowledges Topffer as the father of the modern comic strip. He presents a comic "fold-up" book from 1519 describing the fate of Duke "the Eight Deer Jaguar Claw", and a comic strip version of the "Sorrows of Saint Erasmus" from 1460. It even outlines the possibility that the comic strip was born as early as in 1,300 B.C. in Egypt, in connection with the possible study of the sequential depiction of life on the grave of the scribe Menny (McClaud, 1995). The label of "comics" can also be given to a series from the 18th century, "A Harlot's Progress" by the English painter William Hogarth (Kruml, 2007). Kunzle considers a sequential pictorial presentation as a comics, beginning with the invention of printing press and maps comics from 1450 (Kunzle,1973). The modern comics in its contemporary form is most frequently dated from the mass development of the daily press in the USA and attempts to acquire as many readers as possible (including from the ranks of immigrants who did not master the language, yet understood the "comic strips" of the picture, and so also bought the newspaper). The expression "comics" is an abbreviation of "comic strip" (Groensteen, 2005). A specific branch, most published in the 1960s and 1970s is the "Comix". It is an American underground form of the comics inspired by the hippie movement with subject-matters such as sex, drugs, rock, social and political problems.

Outcault's comics "The Yellow Kids" from 1894 first used both a new combination of text and image - speech bubbles, and a sequence of pictures, as well as the concept of characters who keep returning. In Europe, the French magazine "L'Epatant" (from 1908) 


\section{Acta Educationis Generalis \\ volume 7, 2017, issue 3}

can be mentioned in the context of the modern history of the comics, with Forton's "Pieds-Nickelés" about the adventures of three scoundrels. In the same year in Italy, the magazine for young people, "Corriere dei Piccoli" started, with a large section for comics. There was a different approach to the text of comics in Italy; until the 1960s, the tradition of short speeches under the pictures instead of bubbles continued. The German tradition of Viliam Busche's pictures from the 1870s continued to have a strong influence in Europe in humoristic series.

At the beginning, speech bubbles in panels did not take on in Europe. The pictures were most frequently complemented with text underneath. Sometimes they remained mute. In the second half of the 20th century, work with speech bubbles was more frequent, nevertheless even today certain writers prefer text outside the panel. In the Czech Republic "picture series" were taken up; text in bubbles did not find their place at its beginnings in the 1890s. It was replaced by text under the pictures. Czech writers also worked without text: "Mr. Ťopásek" by Karel Stroff, Karel Ladislav Thuma publishing in "The Young Reader", some stand-alone stories in the Švanda Dudák weekly from the first years of the 20th century. Most frequently in the tradition of the beginnings of the Czech comics from the beginning of the 20th century, comic strips are commented under each picture. For example, this is how Josef Lada, Konstantin Hájek, Josef Kočí, Josef Ulrich, or Karel Vařina worked (Prokůpek, Kořínek, Foret, \& Jareš, 2014).

Comics have also been used in education for over 70 years. In the USA, pedagogical discussions and studies on the benefits of comics in education have been present since the 1940s. However, as a result of prejudices on the abjection or damage of this "genre", it had a difficult path. Alternately, comics were not only rejected as the doom of literacy and a direct threat to moral education, but also celebrated for their strong, educational potential (Sones, 1944). Education curricula were even based on comics. Experimental teaching with the use of comics took place. However, the New York psychiatrist Wertham in his book "Seduction of the Innocent" summarised his opinions on 400 pages dealing with the danger posed by comics of spreading violence, homosexuality, racial stereotypes, rabble-rousing and illiteracy. Subsequent reactions lead to a halt in any state aid to the programme of using comics in schools. It was only in 1970 that teachers found the courage to include once more comics in their teaching. The Pullitzer Price (for journalism) awarded to Spiegelman's "Maus" in 1992 (about the Holocaust in the Second World War) marked a breakthrough. Teaching with the aid of comics spread into all possible fields of school education, and is the subject of university study (History of Comics in Education, 2017).

\section{Comics today}

Today, specialised and academic writings try to define the essence of the singularity of this media. We can label comics in the words of Eisner (1985) as sequential art, or more specifically as the "deliberate juxtaposed sequence of drawn and other pictures aimed at providing information or causing an aesthetic experience" (McClaud, 1995, p. 9). With his definition Harvey (2001) excludes from the realm of comics works working only with a pictorial form. The majority of the other theoreticians of comics do not share this view (e.g. Eisner), and this does not apply either to the history of the European (and Czech comics). Groensteen (2005) even refuses an exact definition as being impossible and warns of the confusing plurality of varied (and as can be seen even contradictory) definitions. He presents several in his "Theory of the Comics" only to refute them all. He 


\section{Acta Educationis Generalis \\ volume 7, 2017, issue 3}

thus points out the need to define comics only generally as a "narrative type with a visual dominance" (Groensteen, 2005, p. 19). One thing on which the majority of theoreticians and writers agree on is that it is a sequential art narrating an action through image, usually combined with words. The basic difference between the comics and other forms of literature and fine art lies in the quite unique communication with the percipient. It is not a literary genre, or an artistic one, but rather an independent medium, as states McClaud (1995). The authors of the theory further diverge in their concept of the dominance of the picture, text, their interweaving and in the labelling of the component units of comics (panel, vignette, field). There is also a lack of uniformity in the view of single-panel "cartoons". This depends more on the writer's feeling and the way the pictorial sequences of the action are processed (which is also possible in a "singleframe" or exceptionally without a frame). A unified definition does not exist, and the variety of comics almost excludes it. We will always find many author-specific creative approaches, which cannot be excluded from the group of comics, but do not fully meet one of the conditions of a certain definition.

Comics are used in school text books (e.g. Wiegerová, Majerčíková, \& Česlová, 2016; Hobbs \& Keddle, 2014 etc.), in non-formal education in informal education - instruction booklets, exercises, or behaviour patterns in unusual situations, as well as an environmental means of education for the population in problematic areas of the world. With this changed view, comics are now used as effective methods of education mainly at secondary school level (Trnová, Janko, Trna, \& Pešková, 2016), and also at a tertiary level (Green, 2013), sporadically at primary level (it is used more to add variety to lessons by individual teachers trying to make their lessons different using alternative methods). They are also popular for leisure time activities and are used spasmodically in after-school clubs; however, systematic work with science comics in preschool practice (in the Czech Republic) is rarely encountered (Wiegerová \& Navrátilová, 2016). Abroad, the educational potential of comics has been confirmed in an ever-growing sphere of educational areas across all levels. It is applied from primary level to the university teaching of medicine (Park et al., 2011; Green, 2013). Cheesman (2006) outlines how comics can be used in all phases of teaching. The properties of comics which support visual literacy (necessary for everyday orientation and reading maps, graphs, tables and for scientific activity in adulthood, X-rays, microscope, scientific images) are used. Comics for teaching foreign languages are popular, for an inquiry-based interest in history, biology, physics and chemistry. Through all age categories of children and students, teachers from the 1 st half of the 20th century confirm the high motivational property of the comics.

Websites for creating one's own comics (children and teachers) are well used. It is possible to follow the expansion of the comics in individual educational fields and the growth of opportunities for working with them.

The power of comics in the development of multi-modal literacy is also confirmed (Kabapinar, 2005; Wiegerová \& Navrátilová 2016).

The juxtaposition itself of pictures in comics forces the reader to activate multimodal thought processes; this presupposes complicated cognitive work by the reader. The great potential for comics in science education and knowledge can be seen clearly (Cheesman, 2006; Wiegerová \& Navrátilová, 2016). In pedagogical strategies, the educational comics can also be a means, aid, pivotal method or platform for building one's own structures. Above all, it can be understood as a complex acquisition method and didactic 


\section{Acta Educationis Generalis \\ volume 7, 2017, issue 3}

means, using visual and literary art and knowledge from pedagogics, pedagogical psychology, development psychology and psycho-didactics for educational purposes (in different phases of education), according to the specific educational needs of children, pupils or students, using different types of solutions.

\section{Inquiry-based teaching and comics}

A focus on the thought processes of developing inquiry-based thought, the overall cultivation of thinking and support for an interest in science topics combines very well with the wide range of opportunities for working with comics. Comics bring nontraditional didactic strategies into the development of science education, which are, however, complicated in terms of their demands on the didactic concept of a content requiring a transdisciplinary approach.

In the inquiry-based science concept of the comics, children learn to work functionally with developing knowledge in the field of science, in accordance with the principles of IBSE through personal experience, investigation, searching for scientific suppositions, verification, argumentation, discussion and new searching, and thus gradually lead to a development in scientific literary, as well as many other types of literacy.

In order to understand concepts, the child must find their own new path, their own solution: create their own construct. Scientific conceptual comics thus prepare educational situations where the activity comes from the children, via a sensitive facilitation by the teacher: from their questions and communication on how they currently understand the phenomena, with the help of suitably chosen questions by the teacher and carefully prepared comics material on the topic of the problem being solved.

This corresponds with Papáček's (2010) perception of inquiry-based education, as acquisition methods of problematic teaching, where knowledge is acquired by solving problems and asking questions. Children use their natural experience, their ideas, they concentrate better and discover for themselves new information, contrasting them with their understanding and trying to unravel any possible conflict. The teacher tries to make a change in the children's alternative concepts (tries to base himself or herself on them, link to them, and push them towards a scientifically correct understanding).

Alternative concepts are the basis for building new and more complete notions. They show us where to begin to teach as well as information essential for planning further steps. The child's initial understanding is used by the teacher in order for the children to develop a new understanding, in a much easier way, as mentions. Comics incite activity in children and teachers. The activation of both these players in the education process is one of the significant mottos of the comics.

For use in preschool education, comics are prepared with topics from everyday life concealing scientific subjects. There are many types and forms of comics. However, working with them is always subject to the principles of inquiry-based education and uses its method. Certain comics use clear thought processes to acquire new science concepts, and some use the idea of completing the comics, children creating their own comics or working on its preparation with a teacher.

Working with all types of comics can be organised as a main educational block for a small group of children, or left as an optional activity as part of the offer of open classroom activities for children. As Cheesman (2006) describes in his study, comics can be used in all phases of educational activity. Comics can be used to deal with almost all science topics; they only need to be adapted to the specific age requirements of the 


\section{Acta Educationis Generalis \\ volume 7, 2017, issue 3}

student, older pupil, younger pupil and pre-schooler. The area of exploration remains, only the level of knowledge varies.

\section{How can we work with comics in preschool?}

Working with comics is not a common didactic strategy in preschools. It brings difficulties even if used in elementary schools. It would therefore seem that their use is more complicated in preschools. However, it is not so. At contemporary busy world, a picture has importance, has an information value. Comics are an ideal tool for the support of creating programme environment in preschools too.

Working with comics belongs to the strategies to which a teacher must prepare thoroughly. Obviously, this is not a strategy which would be among shallow activities.

The comics demand a rigorous preparatory phase when a teacher must clearly consider the topic to be conveyed to children. Technical processing of comics makes an important part of the following preparation. Comic image is always integrated into a concrete story. It usually concerns a few characters who debate the situation or phenomenon. It is very useful if comics convey the real situation that provokes, suggests solutions and motivates children to their own thinking about the situation. Comic drawing should provoke, it should lead to reflection and discussion in group among children.

It is inapprpriate if comic drawing is set in a phantasy or supernatural story. Children would create an unrealistic concept of phenomena and such misrepresenting of natural processes has an impact on incorrect approach movement of children's view of the world around. That is why we should not use a fairy tale in comics although its core is based on the victory of good over evil, but fairy tale does not proceed from real description of situations and is considered to be an appropriate strategy for teaching natural phenomena to children. The current generation of children is different than it was ten or twenty years ago. Even the perception of fairy tales by children is now changing. According to recent British research on childhood, the work with fairy tales reflects attempt by adults to idealize the world of children, but this is not a correct approach.

Conceptual scientific comics must have the following characteristics:

- visual representation of scientific ideas;

- a minimum of text in dialogic form;

- equal presentation of alternative views on the situation and scientifically acceptable perspective;

- scientific ideas are applied to everyday situations based on authentic experience of recipients;

- it need not contain only single scientifically correct response - it often depends on defining the variables. 


\section{Acta Educationis Generalis \\ volume 7, 2017, issue 3}
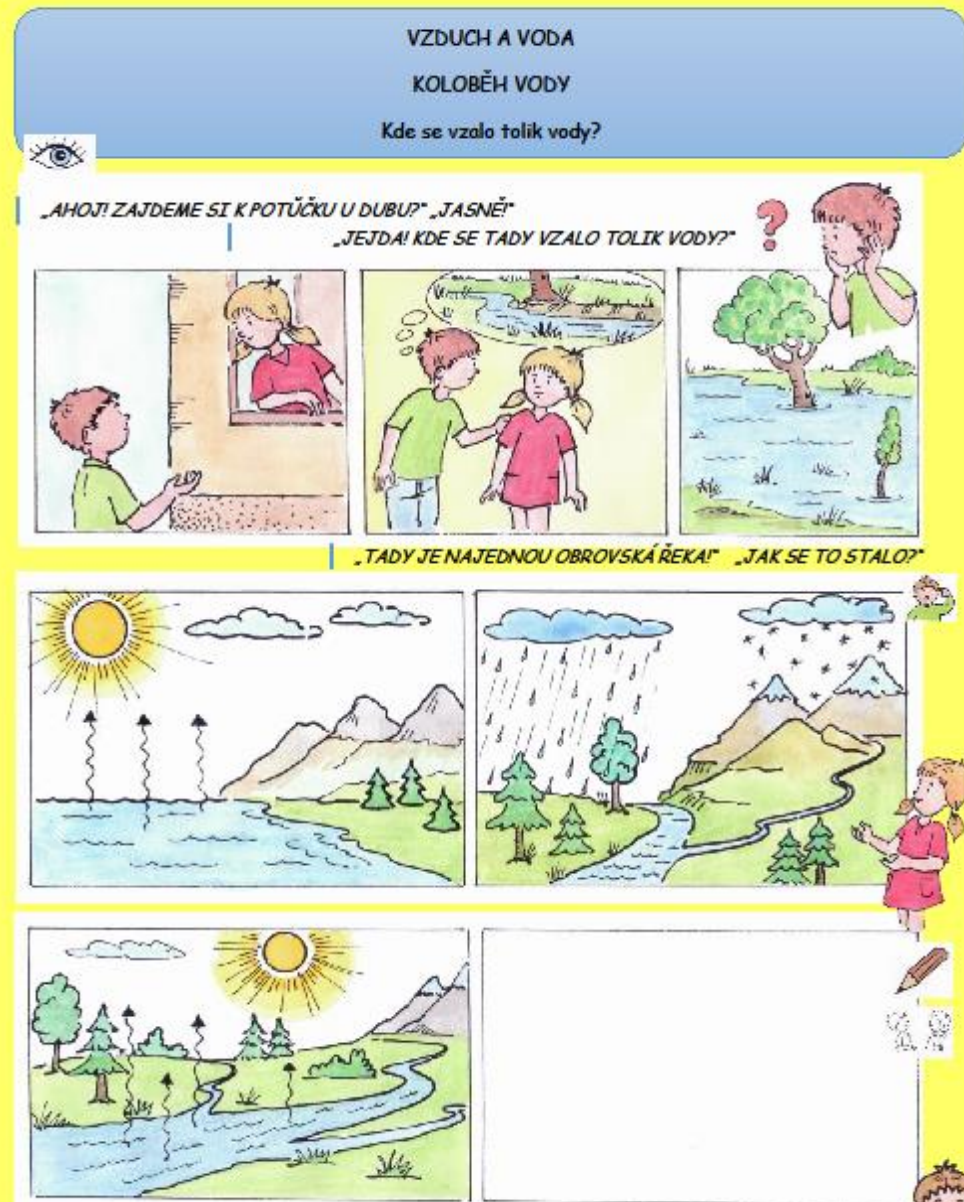

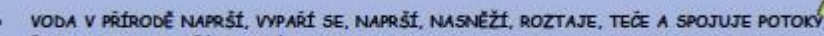
REKY, JEZERA, VYPAR̈I SE, STÁLE DOKOLA.

VELMILEHCE SI NAVLHC̈ETE PRST A ZJISTËTE-COSE STANE 5 VODOU NA NËM? POVËSTE VLHKOU UTËRKU K TEPLU. CO SE STANE? CO POMAAHÁ SLUNCT? WYZKOUŠEJTE POKUS VE FOTOKOMTKSU PROC̄ PRŠtr

- W-TEPLEM SE $Z$ VODY NA ZEMI OOPAR̃A SPOUSTY MALÝCH KAPIĆEK - PROMÉNI SE $V$ NEVIDITELNOU PARU, A TA STOUPA VZOUCHEM NAHORU. TAM SE PARA OCHLADI A ZNOVU SE Z NI

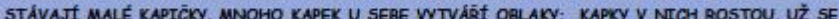
NEUDRZ̈I, A TAK PADAJI ZPÁTKY DOLU. KAPKY NEBO VLOĆKY. CO NASNĚŽŻ, TO ZASE TEPLÝ VZOUCH

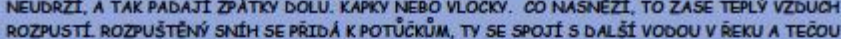
DÁL KOYŻ ROZTAJE HODNÉ SNĚHU, NEBO NAPRŠI HODNË VODY, POTOKY A REEKY JSOU PAK MNOHEM vĚtš̆f

Figure1. Illustration of comics 1. 
Acta Educationis Generalis

volume 7, 2017, issue 3

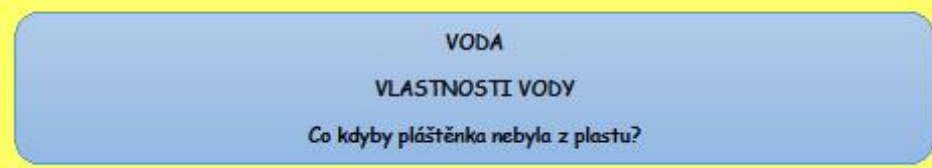

2

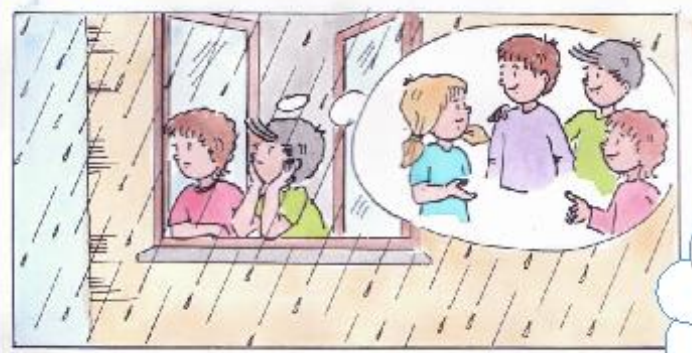

NA PLÁŠTĚNCE

TOLIK VODY.

ALE MY JSME SUŠÍ

???
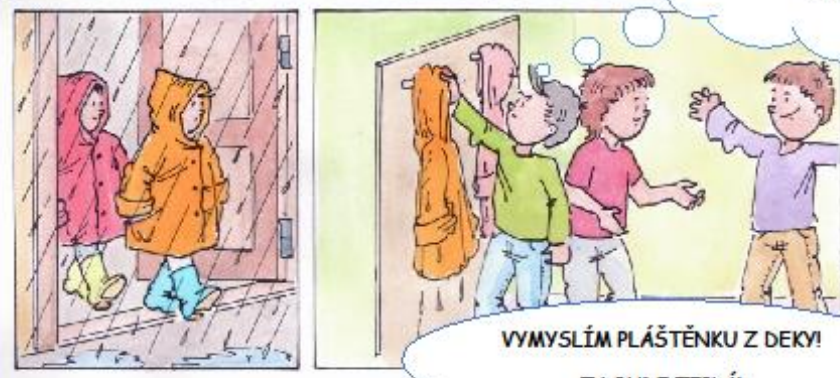

VYMYSLÍM PLÁŠTĚNKU Z DEKY!

TA BUDE TEPLÁl

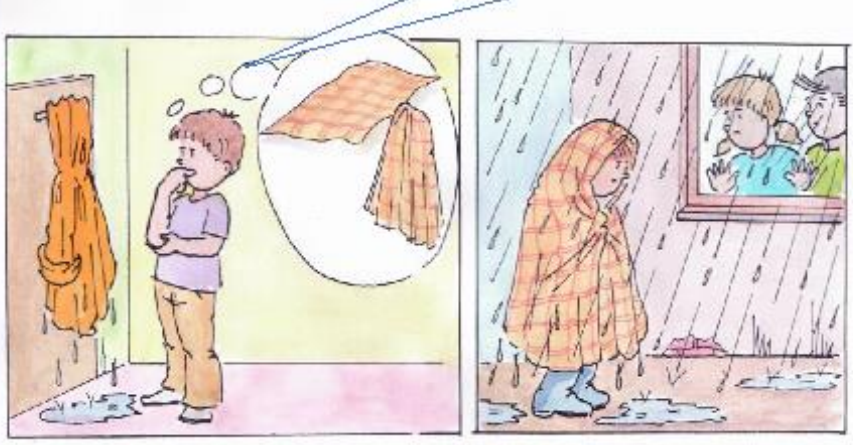

s

Figure2. Illustration of comics 2. 


\section{Acta Educationis Generalis \\ volume 7, 2017, issue 3}

\section{Conclusion}

In the process of science education, it is important that children learn to develop their thinking, to learn to argue, to actively deduce and create the concepts. Based on his own experience which is important part of scientific discovery from child's birth already, a child should learn to develop the knowledge through exploration, verification and constant search for scientific assumption and arguments. Comics can be very helpful in this effort. But the teacher has an important role in this process. The teacher is expected to:

- realise possible ways of concept development in the area under consideration;

- be competent to create tasks which stimulate and support educational process;

- have confidence in himself related to personal understanding of the topic, to be capable to accept different opinions and to react on them;

- be competent to organise and to manage the group of children the way that he supports conceptual learning.

\section{References}

Cheesman, K. (2006). Using comics in the science classroom. Journal of College Science Teaching, 35(4), 48-51.

Eisner, W. (1985). Comic \& sequental art. Tamarac, Florida: Poorhouse Press.

Green, M. J. (2013). Teaching with Comics: A Course for Fourth-Year Medical Students. Bioethics Quarterly, 34(4), 74-76.

Groensteen, T. (2005). Stavba komiksu. Brno: Host.

Harvey, R. (2001). Comedy at the Juncture of Word and Image: The Emergence of the Modern Magazine Gag Cartoon Reveals the Vital Blend. In R. Varnum \& C. T. Gibbons (Eds.), The Language of Comics: Word and Image. Jackson, MS: University Press of Mississippi.

Havice, W. (2014). Integrative STEM Education - Developing Innovators, Educating Creative Learners. National drop out preventine center. Network, 24(1), 35-39.

History of Comics in Education. Retrieved from http://www.geneyang.com/comicsedu/ history.html

Hobbs, M, \& Keddle, J. S. (2014). Your Space. Cambridge University Press.

Jakabčic, I. (2002). Základy vývinovej psychológie. Bratislava: Iris.

Kabapinar, F. (2005). Effectiveness of Teaching via Concept Cartoons from the Point of View of Constructivist Approach. Educational Sciences: Theory \& Practice, 5(1), 135-146.

Kim, J., Chung, M. S., Jang, H. G., \& Chung, B. S. (2016). The use of educational comics in learning anatomy among multiple student groups. Anatomical Sciences Education, 10(1), 118-123.

Kopáčová, J. (2003). Bádatel'ské aktivity - nástroj rozvoja kompetencií žiaka. In Cesty demokracie vo výchove a vzdelávaní. Bratislava: PdF UK.

Kruml, M. (2007). Comics: Stručné dějiny. Praha: Comics Centrum.

Kunzle, D. (1973). The history of Comic Strip. Berkeley: University of California Press.

McClaud, S. (1995). Understanding comics. Northamption: Kitchen Sink Press.

Papáček, M. (2010). Badatelsky orientované př́rodovědné vyučování - cesta pro biologické vzdělávání generací Y, Z a Alfa? Scientia in educatione, 1(1), 33-49. 


\section{Acta Educationis Generalis \\ volume 7, 2017, issue 3}

Prokůpek, T., Kořínek, P., Foret, M., \& Jareš, M. (2014). Dějiny československého komiksu 20. století. Praha: Akropolis.

Sones, W. W. D. (1944). The Comics and Instructional Method. Journal of Educational Sociology, 18(4), 232-240.

Svatoš, T., \& Maněnová, M. (2017). Learning from Visual Materials: A Psycho-Didactic Experiment. Acta Technologica Dubnicae, 7(1), 44-48. doi: 10.1515/atd-2017-0003

Tatalovic, M. (2009). Science comics as tools for science education and communication: A brief, exploratory study. Journal of Science Communication, 8(4), 1-17.

Trnová, E., Janko, T., Trna, J., \& Pešková, K. (2016). Typy vzdělávacích komiksů a analýza jejich edukačního potenciálu pro př́rodovědnou výuku. Scientia in Educatione, 7(1), 49-64.

Wellner, L. (2016). Speak of the Bubble - Constructing Comic Book Bubbles as Literary Devices in a Primary School Classroom. Journal of Graphic Novels and Comics, 8(2), 1-21.

Wiegerová, A., \& Navrátilová, H. (2017). Let's Not Be Scared of Comics (Researching Possibilities of Using Conceptual Comics in Teaching Nature Study in Kindergarden). Procedia - Social and Behavioral Sciences, 237, 1576-1581.

Wiegerová, A., Majerčíková, J., \& Česlová, G. (2016). Prvouka pre 2. ročník základnej školy. Bratislava: SPN. 